\title{
ANALYSIS OF VIBRATIONS GENERATED BY THE MULTI-BODY MODEL OF A PLANETARY GEAR
}

\begin{abstract}
SUMMARY
In the paper the dynamic model of an one-stage planetary gear was presented. The model was developed on the basis of a multi-body dynamics method. To conduct dynamic simulations the specialized multi-body dynamics software was used. In the study the tests results for steady state operations of the planetary gear were presented. In the paper the meshing force signals were analyzed. The vibrations generated by the model consist of carrier and gear meshing frequency harmonics. On the spectra the amplitude modulations of the gear meshing frequencies harmonics were observed.
\end{abstract}

Keywords: gear model, planetary gear model, multi-body dynamics model, condition monitoring, meshing forces

\section{ANALIZA SYGNAEÓW WIBROAKUSTYCZNYCH GENEROWANYCH PRZEZ MODEL PRZEKLADNI PLANETARNEJ}

$W$ artykule zostat przedstawiony model dynamiczny jednostopniowej przektadni planetarnej. Zbudowano go, korzystając z metody układów wieloczłonowych. W celu przeprowadzenia analiz dynamicznych wykorzystano specjalistyczne oprogramowanie komputerowe. W pracy przedstawiono wyniki symulacji pracy przekładni przy stałej prędkości obrotowej $i$ stałym obciązeniu. Badanymi sygnałami były zmiany wartości sit podczas pracy przekładni, generowane przez algorytm kontaktów między wspótpracującymi zębami kót zębatych. W wyniku oddziatywań pomiędzy elementami przekladni generowane sa sygnaty o częstotliwościach zwiazanych z obrotami jarzma oraz praca zazębienia kót zębatych. W paśmie częstotliwości zazębienia pojawiaja się składowe podstawowe oraz ich modulacje.

Stowa kluczowe: model przekładni, model przektadni planetarnej, metoda układów wieloczłonowych, diagnostyka techniczna, sity zazębienia

\section{INTRODUCTION}

In the paper the simulations results for one stage planetary gear model have been presented. The purpose of the analysis was to simulate and verify vibration signals generated by the model of the planetary gear. The multi-body dynamics method has been used to model dynamic interactions occurring during work of the gears.

The dynamic models of the gears developed on the basis of multi-body dynamic method were presented in the papers (Dresig 2005, Kong et al. 2008, Sommer et al. 2011, Wu et al. 2011). In the study (Kong et al. 2008) model of a large industrial gearbox developed in the specialized multi-body dynamics software MSC ADAMS was presented. The authors presented a rigid-elastic model of gears. In this model shafts and gear's bodies are rigid and the contact surfaces between teeth are elastic. The simulation results for other technical states (broken tooth) in this paper were presented. The other model of a spur gears was presented in (Sommer et al. 2011). In this study the multi-body kinematic model of a slider-crank mechanism was presented, the model was developed by a specialized software. In the model authors assume a non-linear contacts between teeth of spur gears.
The simulation results were presented for defects of gears such as a chipped and eccentric tooth. The application of the multi-body dynamics method for modeling of a planetary gear dynamics was presented in the articles (Dresig 2005, Wu et al. 2011). In this paper the analyzes of a contact force between a planetary gear teeth in mesh were conducted. The authors noticed that value of analyzed force strongly depend from contact ratio for each gear. The analysis of local faults due to chipped tooth for sun gear were presented, too. With comparison to the perfect geometry a planetary gear with a chipped tooth of the sun gear, in the tests caused large changes of an angular velocity magnitude. The other model presented in the paper (Dresig 2005) permits to conduct the dynamic simulation of planetary gearboxes with arbitrary number of elastically mounted planets, considering the stiffness characteristics in the tooth contacts, as well as all relevant toothing parameters, such as number of teeth, pressure angle, etc.

In the study conducted so far there is no particular analysis of spectrum structure of vibrations generated by the multibody dynamics models. In the papers (Dresig 2005, Wu et al. 2011) there is no analysis of gear meshing frequencies and its modulations generated by a planetary gear system. 


\section{PRELIMINARY MODEL STUDIES}

In this chapter the preliminary analyzes of the one-stage planetary gear dynamic model have been presented. In the study the structure containing a sun and planet gear was modeled. In this structure an axis of the planetary gear was constrained, as a result, this model was reduced to a spur gear. Firstly, the three-dimensional CAD model was developed, then it was imported to the MSC ADAMS software. The software allows to conduct dynamic simulations of the model on the basis of a multi-body dynamics method. The model of two gears in mesh is presented in Figure 1.

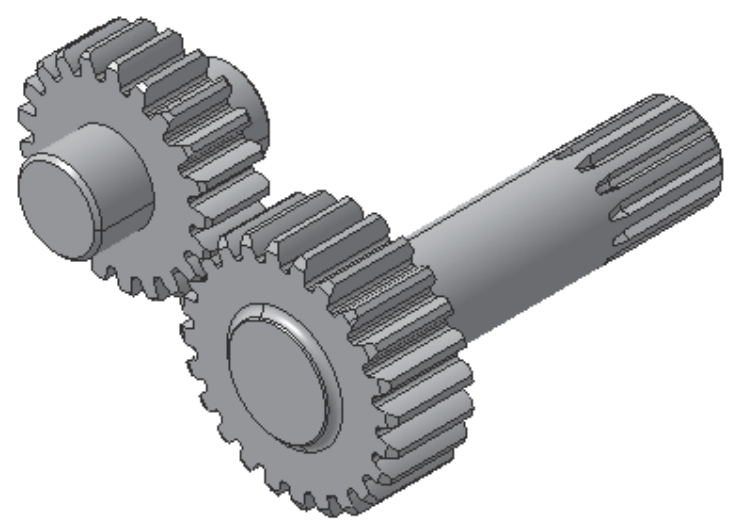

Fig. 1. Model of two gears in mesh

The motion of a multi-body system can be described in general form by the set of equations (1-2) presented below (Wojtyra et al. 2007).

$$
\begin{aligned}
& G(y, \dot{y}, t)=0, \quad y(t=0)=y_{0} \\
& y=\left[u^{T}, p^{T}, \varepsilon^{T}, r^{T} \varphi^{T}, \lambda^{T}, F^{T}, \bar{N}^{T}\right]^{T}
\end{aligned}
$$

Where $u$ is a velocity vector, $p$ is a generalized momentum, $\varepsilon$ is an angular velocity, $r$ is a coordinate of the origin of the body reference, $\varphi$ is an Euler angles, $\lambda$ is a Lagrange multipliers, $F$ is an external force vector, $N$ is an external torque vector.

For simulation of a vibration signal for gears in mesh the contacts between gears bodies were modeled. In the presented model gears bodies and shafts are rigid, but contact surfaces between gears teeth are elastic. The gears and shaft were fixed, the revolute joints were used between the shafts and ground. The constant rotational motion was applied on the one shaft and resistive torque on the other one. The meshing of the gears was modeled on the basis of contacts, to this aim the ADAMS Impact Algorithm (Kong 2008, MSC Inc. 2011) was used, Figure 2.

Equation (3) describes a contact force in the ADAMS Impact algorithm. The contact force is composed of two parts: the elastic component and damping force, which is a function of the contact-collision velocity. By the definition of the step function equation (4), the damping force is defined as a cubic function of the penetration depth (Sommer 2011, MSC Inc. 2011).

$$
\begin{aligned}
& F=\left\{\begin{array}{cc}
K\left(x_{0}-x\right)^{e}+C S \dot{x} & x<x_{0} \\
0 & x \geq x_{0}
\end{array} .\right. \\
& S=\left\{\begin{array}{cl}
0 & x>x_{0} \\
(3-2 \Delta d) \Delta d^{2} & x_{0}-d<x<x_{0} \\
1 & x \leq x_{0}-d
\end{array}\right.
\end{aligned}
$$

Where $\Delta d=x_{0}-x_{1}$ is a deformation of a body, $K$ is a contact stiffness, $e$ is a force exponent, $C$ is a damping parameter and penetration depth is assigned by $d$. The stiffness between teeth pair in contact can be described by the Hertz elastic contact theory, equation (5). In this model the stiffness is described by a pair of ideal cylinders in contact (Johnson 1985).
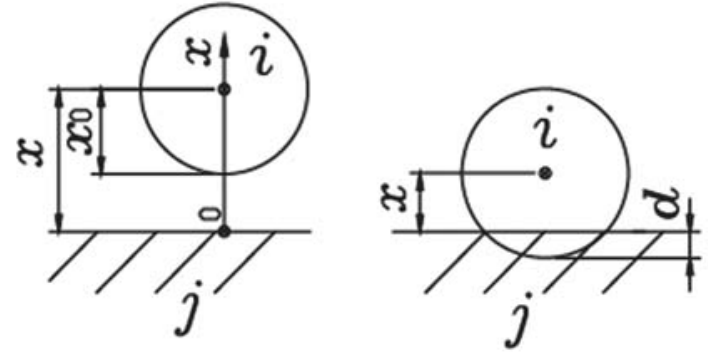

Fig. 2. Contacts model in ADAMS

$$
\begin{gathered}
K=\frac{4}{3} R^{\frac{1}{2}} E^{*}=\frac{4}{3}\left[\frac{i d_{1} \cos \left(\alpha_{t}\right) \tan \left(\alpha_{t}^{\prime}\right)}{2(1+i) \cos \left(\beta_{b}\right)}\right]^{\frac{1}{2}} E^{*} \\
\frac{1}{E^{*}}=\frac{1-v_{1}^{2}}{E_{1}}+\frac{1-v_{2}^{2}}{E 2} \\
\beta_{b}=\operatorname{atan}\left(\tan \beta \cos \alpha_{t}\right)
\end{gathered}
$$

In the equation above the $R$ is an equivalent radius of two contacting bodies, $E^{*}$ is an equivalent Young's modulus of two contacting bodies, $i$ is a gear ratio, $d_{1}$ is a diameter of standard pitch circle, $\alpha_{t}{ }^{\prime}, \alpha_{t}$ is a transverse pressure angle at engaged and standard pitch circle, $\beta, \beta_{b}$ is a helical angle at the pitch and base circle, $v_{1}, v_{2}$ is a Poisson ratio of the pinion and gear. The Young's modulus of pinion and gear are described by $E_{1}, E_{2}$, respectively. In the model it was assumed that the gears are made from the steel with Young modulus $2.1 \cdot 10^{11} \mathrm{~Pa}$, and Poisson ratio 0.3 . The equivalent Young modulus for two bodies in contact $1.153 \cdot 10^{11}$ $\mathrm{Pa}$. The contact stiffness calculated on the basis on the equation (5) yields to $K=3 \cdot 10^{5} \mathrm{~N} / \mathrm{mm}^{3 / 2}$. The damping coefficient takes value from 0.1 to $1 \%$ of $K$, in the study $C=3000 \mathrm{Ns} / \mathrm{mm}$ was assumed. Other parameters for con- 
tact algorithm: force exponent $e=1.3$ and penetration depth $d=0.3 \mathrm{~mm}$

The tests results for the multi-body model of gears, were presented below. In the simulation next parameters were assumed: rotational speed $10 \mathrm{~Hz}$, torque $200 \mathrm{Nm}$, time of simulation $1 \mathrm{~s}$ and number of steps 5000 . To present the contact force changes in meshing process, the meshing force was plotted in the window (length of $0.06 \mathrm{~s}$ ), and presented in Figure 3.

In Figure 3 the signal of meshing force measured in vertical direction was presented. The signal was calculated on the basis of the contact algorithm between two gears. The presented signal is periodic, changes of signal amplitude are due to number of teeth in engage. The Figure 4 presents spectral analysis of this signal. On the spectrum the Gear Meshing Frequency harmonics (GMF) are clearly distinguishable. According to the equation (6) the GMF should be localized on 240, 480, 700 and $940 \mathrm{~Hz}$.

$$
F_{m}=z F_{r o t} n
$$

In the equation (6) $F_{m}$ is a gear meshing frequency, $F_{r o t}$ is a rotational frequency, $z$ is a teeth number and $n$ is a number of harmonic.

To sum up, the model of the spur gears allows for simulations of a meshing force in a steady state conditions. The correctness of the results was confirmed by correct localization of GMFs for simplified model.

\section{THE PLANETARY GEAR MODEL}

The planetary gear model was developed for the planetary gear MERCURY 1-A. In the model all gear dimensions and toothing parameters were reproduced. The planetary gear MERCURY 1-A is a part of the test rig in the Laboratory of Technical Diagnostics at the AGH University of Science and Technology, the test rig was designed for simulation of vibrations generated by the planetary gear under time varying operations. The planetary gear MERCURY 1-A was presented in Figure 5.

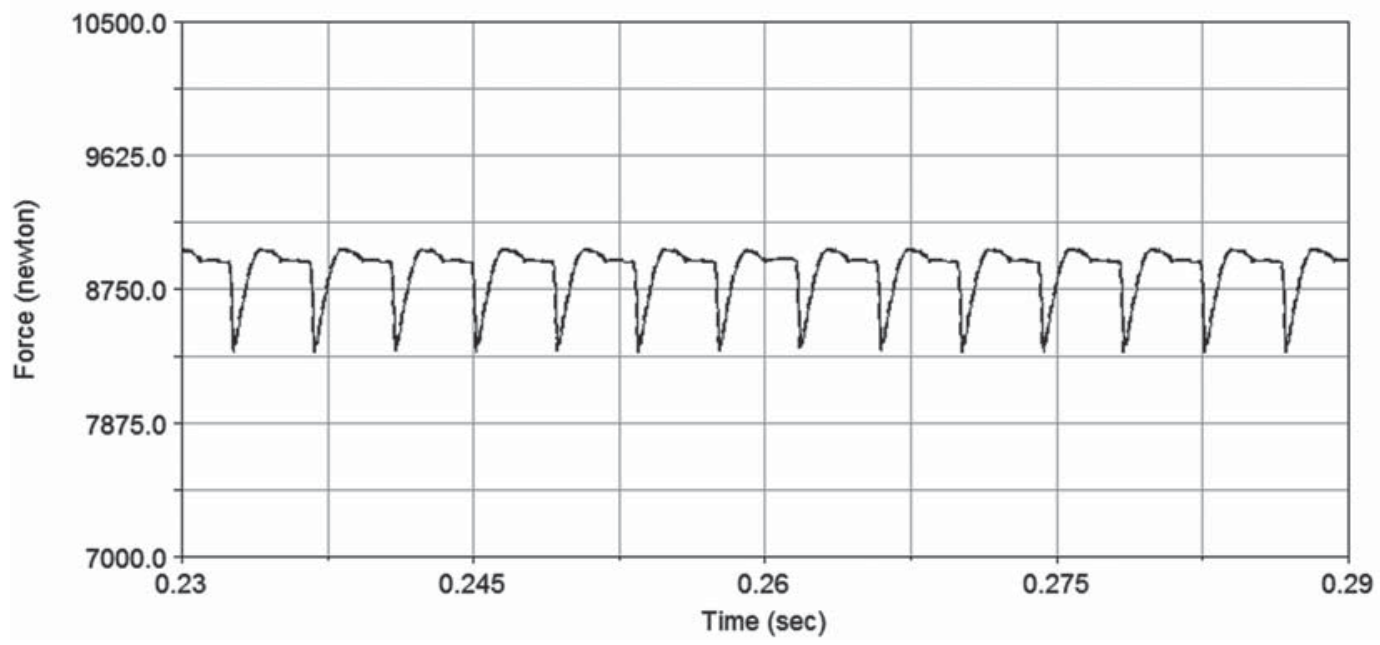

Fig. 3. Meshing force

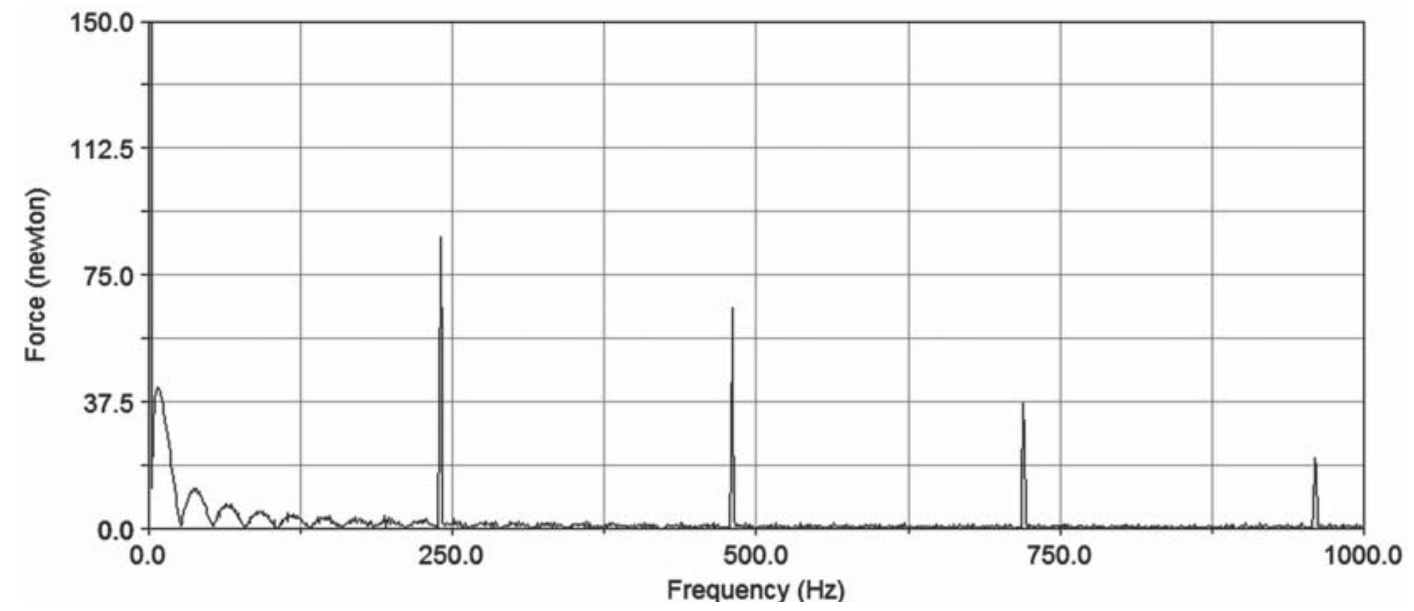

Fig. 4. Spectrum of meshing force 


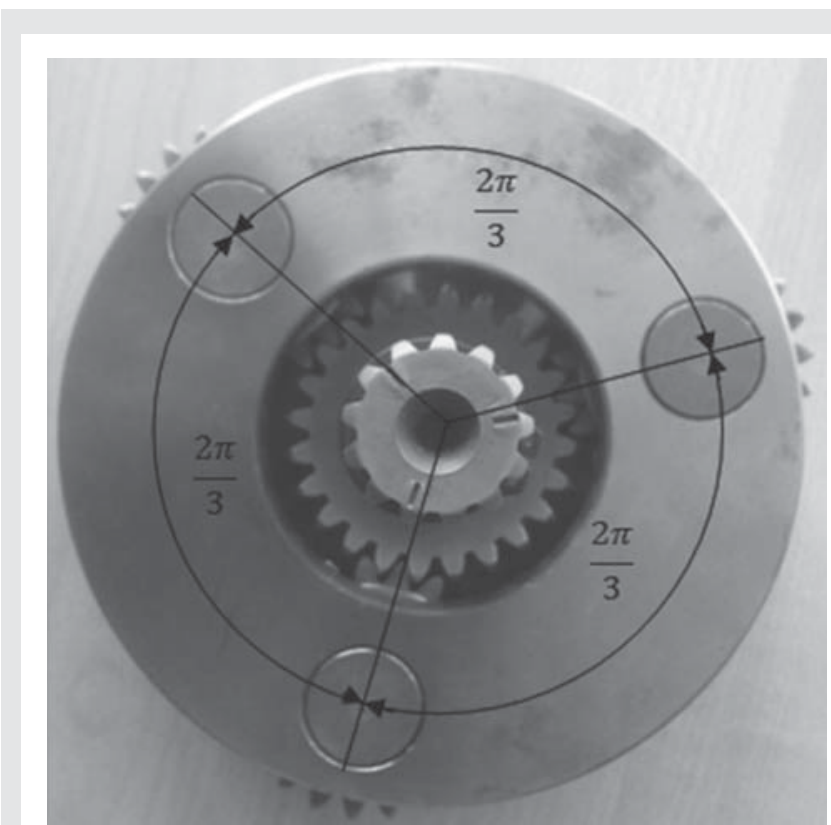

Fig. 5. Planetary gear MERCURY 1-A

To build the model next assumptions were done: gears and shafts are rigid, contact surfaces are elastic, ideal teeth profile, gears are made from steel without surface treatment, lubrication neglected. Firstly the CAD model was developed, next it was imported to the ADAMS environment. In the multi-body dynamics software the constraints and forces were modeled. The three-dimensional CAD model of the planetary gear is presented in Figure 6.

To conduct dynamic simulations of the model, forces and torques were defined. In the model the torque of $60 \mathrm{Nm}$ was applied on the carrier and constant rotational speed of $30 \mathrm{~Hz}$ was applied on the shaft of the sun gear. To verify the model, firstly displacements of the mass centers of the planet gears in the global coordinates system, during simulation was presented, Figure 7.

On the plots above the phase relations between the positions of each gear resulting from the geometric properties are visible. In the next chapter the analysis of vibration signals generated by the model were presented.

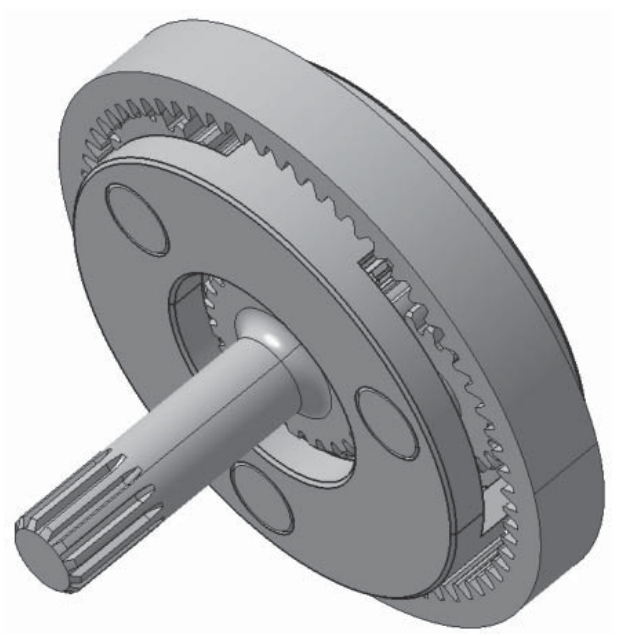

Fig. 6. Planetary gear CAD model

\section{SIMULATION RESULTS}

In this chapter the model simulations results were presented. The simulations were conducted for the same parameters and operations as presented in the previous chapter. In the study the meshing force signal was measured in the vertical direction in global coordinates during tests. The analysis of the tests results were presented in Figure 8 and 9.

The changes of the contact force between the planet and ring gear are presented in Figure 8, while in Figure 9 the spectral analysis of this signal was presented. On the spectrum characteristic frequencies of the planetary gear system are observable. The frequency of $8 \mathrm{~Hz}$ is related to the carrier rotations $f_{a}$, equation (7).

$$
f_{a}=f_{1} \frac{z_{1}}{z_{1}+z_{2}}=f_{1} \cdot 0.266
$$

In the equation above $z_{1}=24$ is a teeth number of sun gear, $z_{3}=66$ is a the teeth number of ring gear and $f_{1}=30 \mathrm{~Hz}$ is a the rotational speed of the input shaft.

$$
f_{12}=f_{23}=f_{1} \frac{z_{1} z_{2}}{z_{1}+z_{2}}=f_{1} \cdot 17.6
$$

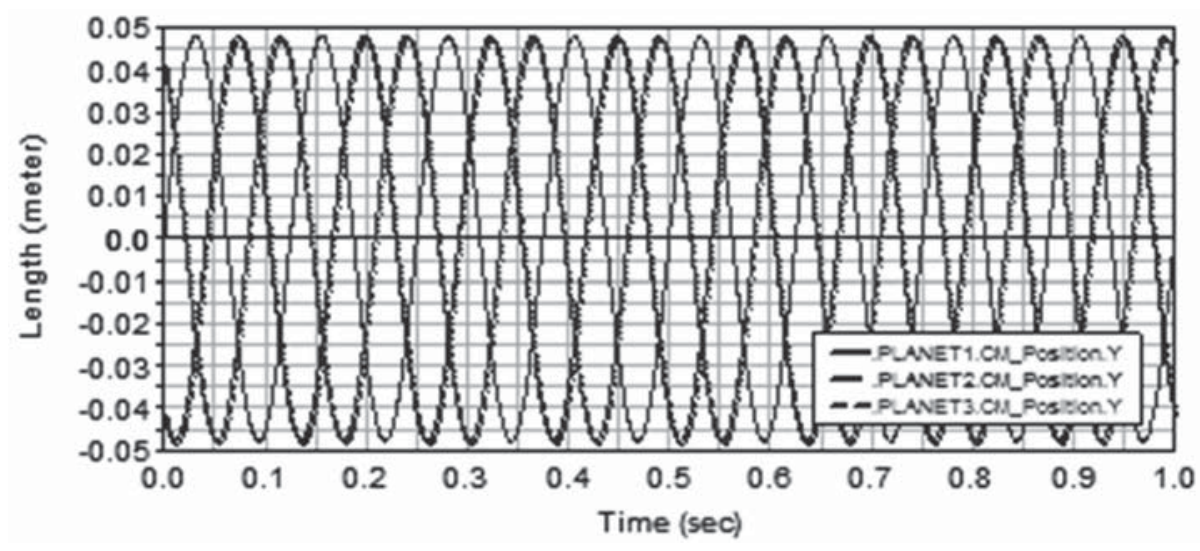

Fig. 7. Planet gear center mass position during simulation 


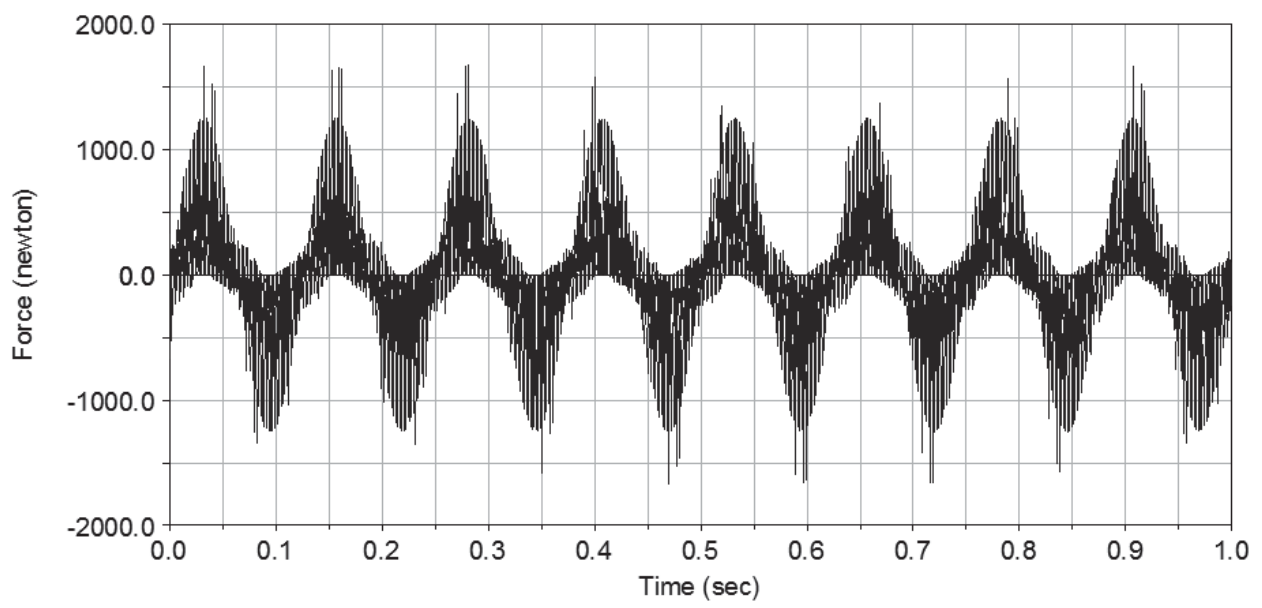

Fig. 8. Meshing force generated by planet and ring gear

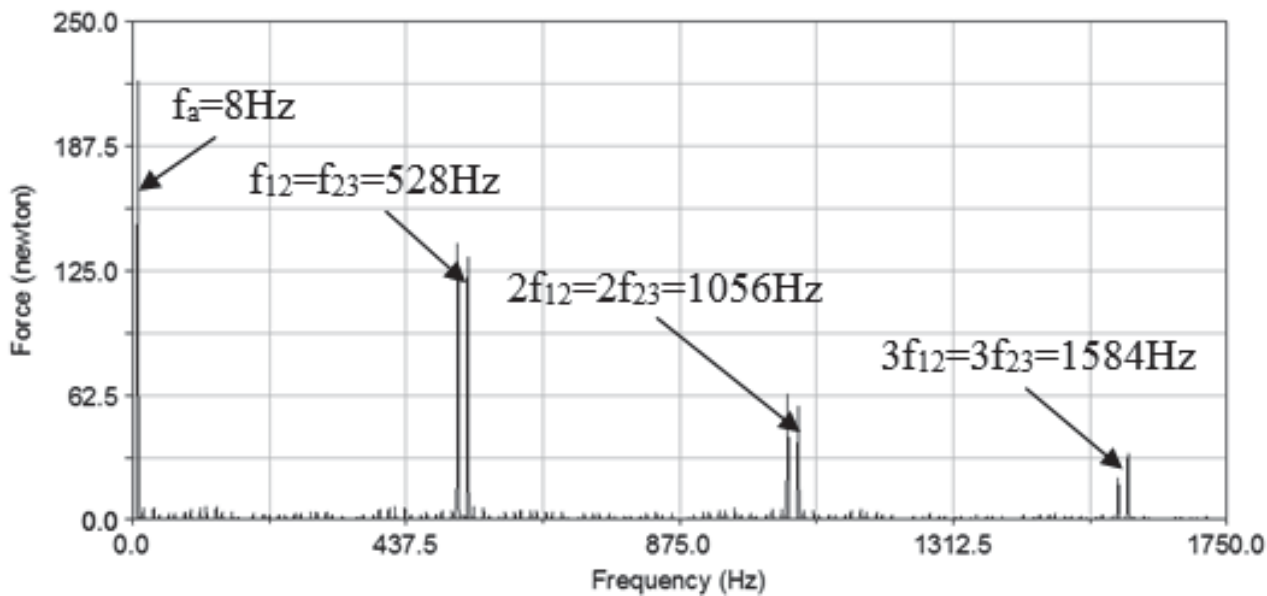

Fig. 9. Spectral analysis of meshing force generated by planet and ring gear

The planetary gear meshing frequency harmonics are presented by the equation (8), the first three harmonics should be localized on 528, 1056 and $1584 \mathrm{~Hz}$. On the spectrum one can observe that the GMFs were reduced, only modulations of this frequencies by carrier rotation speed are visible. The reduction can be caused by ideal geometry of the planetary gear system. The meshing forces generated by three planet gears were plotted in Figure 10.

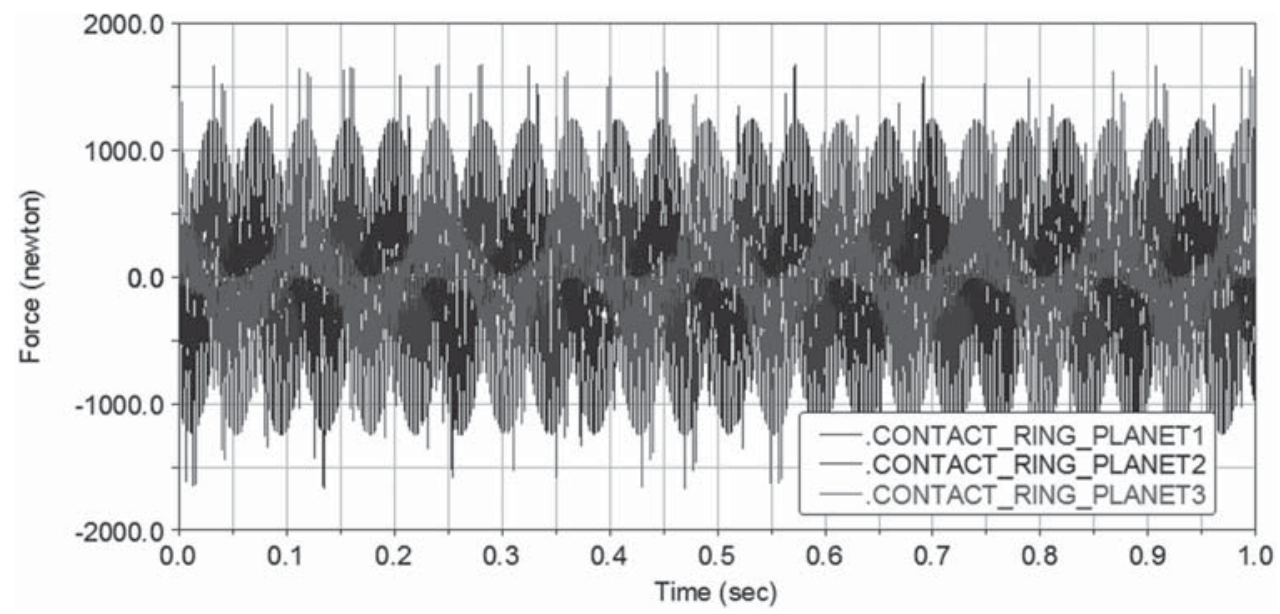

Fig. 10. Meshing forces generated by three planet gears and ring gear 


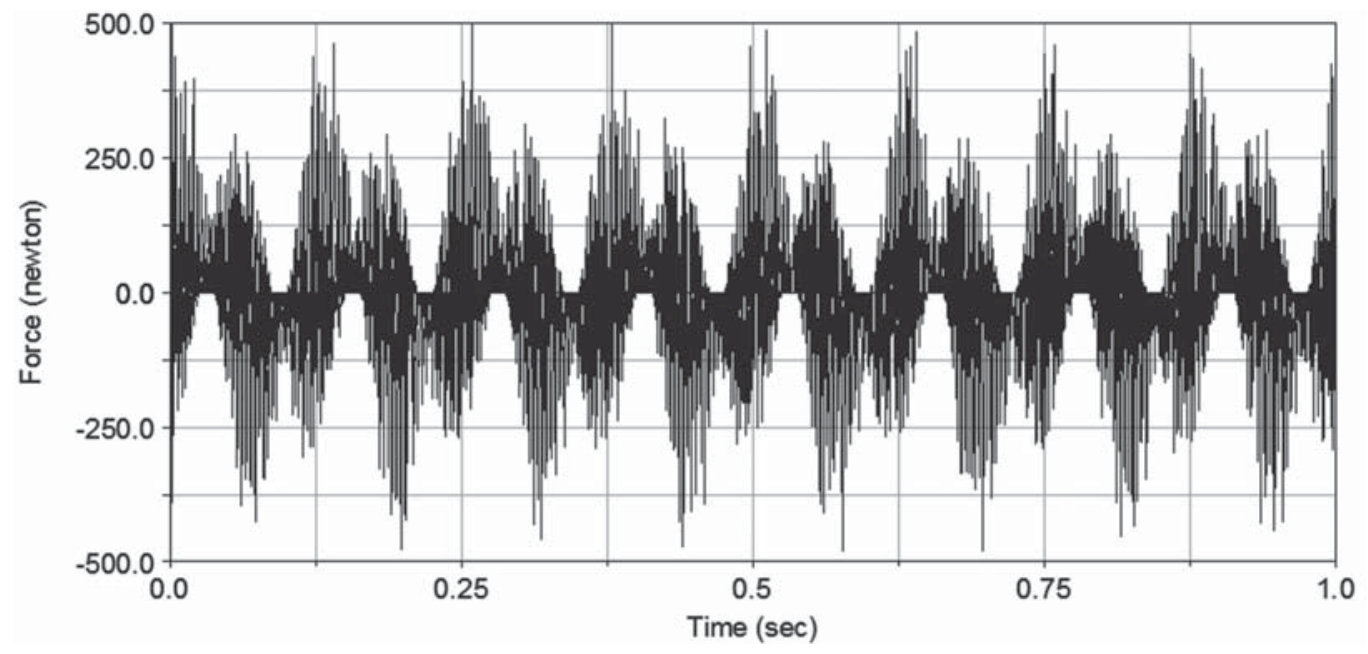

Fig. 11. Meshing force generated by planet and sun gear

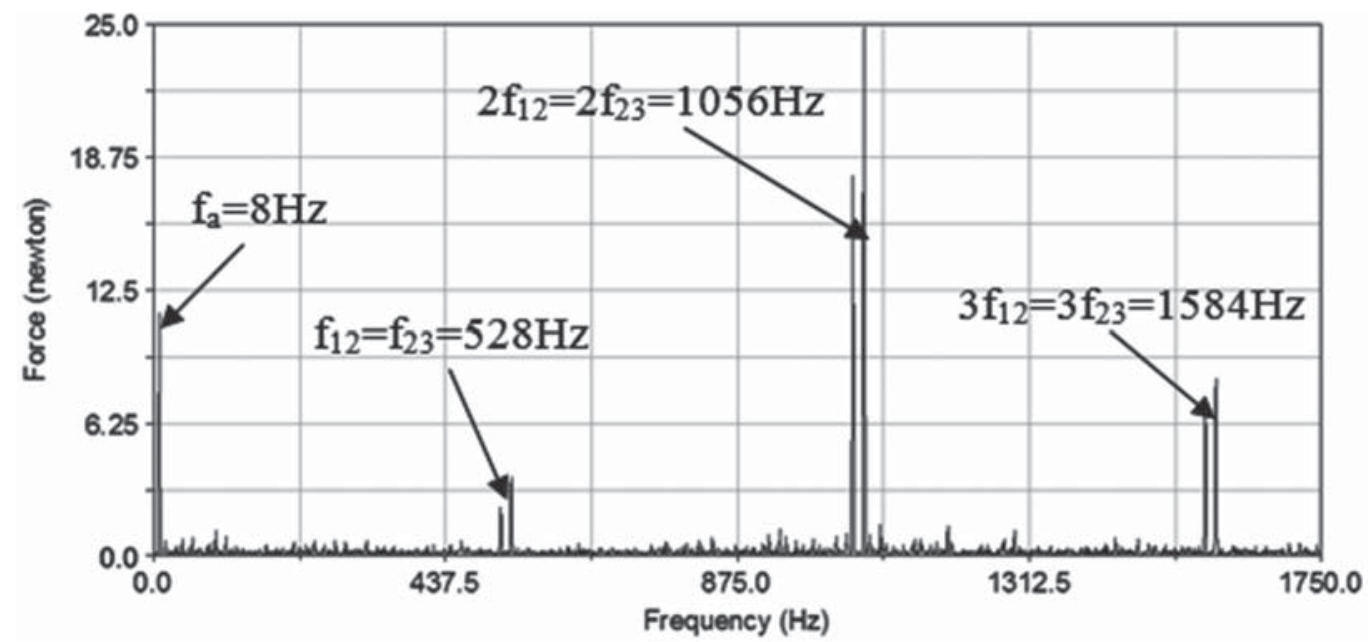

Fig. 12. Spectral analysis of meshing force generated by planet and sun gear

The meshing forces generated by the planet and ring gear were plotted in figure above. The phase shift between these signals is clearly observable.

In the next part of this chapter analogous analysis for the signals generated by the sun and planet gears were presented.

As it is observable in Figure 11 for this case the changes of the force signal are similar as for the planet-ring gear meshing. The periodical changes of the force sign are due the position changes of the planet gears during operations in the global coordinate system. On the spectrum presented in Figure 12, it is visible that for this case the even modulations have signify bigger amplitudes.

\section{CONCLUSIONS}

In the presented paper the tests results of the planetary gear dynamic model were presented. In the conducted simulations the vibration signals were generated by the contact algorithm, acting during interactions between gears teeth. On the spectra of meshing force the harmonics of carrier and gear meshing frequencies harmonics are observable. The localization of the gear meshing frequency harmonics is correct for assumed operation conditions. It can be concluded that in the presented model contact forces between the sun and planetary gears are three times smaller, than generated by ring and planet gear meshing process. In the paper the preliminary tests of the multi-body model of planetary gear were presented. In the future the model will be extended, e.g. by application of flexible bodies for gears and shafts, taking into account lubrication, analysis of signals propagation paths from meshing points to sensor located on the gearbox housing.

This study was supported by Grant No. 15.11.130.146

\section{References}

Dresig H., Schreiber U. 2005, Vibration Analysis for Planetary Gears, Proc. of the International Conference on Mechanical Engineering and Mechanics, Nanjing, China.

Johnson K. L. 1985, Contact Mechanics, Cambridge University Press. 
Kong D., Meagher J. M., Xu C., Wu X., Wu Y. 2008, Nonlinear Contact Analysis of Gear Teeth for Malfunction Diagnostics, Proc. of the IMAC XXVI Conference and Exposition on Structural Dynamics, Orlando, Florida.

Sommer A., Meagher J., Wu X. 2011, Gear Defect Modeling of a Multiple-Stage Gear Train, Modeling and Simulation in Engineering, vol. 2011, pp. 1-8.
Wojtyra M., Frączek J. 2007, Metoda układów wieloczłonowych $w$ dynamice mechanizmów, Oficyna Wydawnicza Politechniki Warszawskiej.

Wu X., Meagher J., Sommer A. 2011, A Differential Planetary Gear Model with Backlash and Teeth Damage, Rotating Machinery, Structural Health Monitoring, Shock and Vibration, no. 5, pp. 203-215.

MSC Inc. 2011, MSC ADAMS reference manual. 